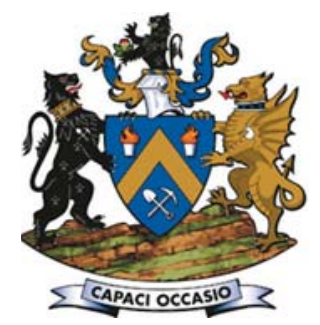

\title{
Investigation of zinc and lead contamination of soil at the abandoned Edendale mine, Mamelodi (Pretoria, South Africa) using a field-portable spectrometer
}

\author{
by J-N. Oyourou*, R. McCrindle*, S. Combrinck*, and C.J.S. Fourie ${ }^{\dagger}$
}

\section{Synopsis}

Many mines in South Africa were inappropriately closed and left unattended during the last century. These old mines are potential sources of environmental pollution and may pose a health risk to local populations, since the surrounds contain elevated levels of toxic elements. Soil from the old Edendale lead mine property in Mamelodi Extension 11, east of Pretoria, which was suspected to be contaminated with lead, was analysed. The mine, which primarily extracted galena, was decommissioned in 1938. During this study, the old mine property and surrounds were screened for zinc and lead using a field-portable X-ray fluorescence (pXRF) spectrometer. The metal concentrations, which ranged from 18 to $7300 \mathrm{mg} / \mathrm{kg}$ for zinc and from 50 to $21000 \mathrm{mg} / \mathrm{kg}$, for lead, were plotted together with the GPS coordinates to produce a concentration distribution map for lead and zinc. This map revealed three anomalies of unacceptably high concentrations, possibly corresponding to areas where ore had been piled or dumped to waste from the old mine. Thirty-six of the soil samples that were analysed by pXRF on site were selected and analysed in the laboratory using inductively coupled plasmaoptical emission spectrometry (ICP-OES) for verification purposes. The zinc and lead concentrations obtained from the two analytical methods were compared using linear regression analysis. Excellent correlation was obtained between the results from the two methods ( $\mathrm{r}^{2}=0.99$ for zinc and $\mathrm{r}^{2}=0.95$ for lead).

Keywords

soil pollution, zinc, lead, portable XRF.

\author{
Introduction \\ Early economic development in South Africa \\ was based mainly on mining. However, these \\ activities left a legacy of approximately 6000 \\ improperly closed mines scattered throughout \\ the country (SAI, 2009; van Schie, 2012). Due \\ to their proximity to settlements, these \\ abandoned mines may pose a potential health \\ risk to humans and an environmental hazard. \\ Mining activities generate large amounts of \\ waste, mostly in the form of overburden and \\ process tailings, which often contain high \\ concentrations of toxic elements. Bioavailable \\ toxic elements can contaminate crops growing \\ in the polluted area (Kala, 2010; Marwa, \\ Meharg, and Rice, 2012) or eventually migrate \\ and detrimentally affect the groundwater \\ (Rösner and van Schalkwyk, 2000). Moreover, \\ sulfides accumulated in mine waste generate \\ acid minewater (Rösner and van Schalkwyk,
}

2000). Unfortunately, owners of mines, closed before the promulgation of the Minerals Act more than twenty years ago (Act 50 of 1991), avoided the compulsory rehabilitation of the environment enforced by this legislation. Toxic elements, such as lead, which were confined within ores, may become exposed through mining and are therefore more easily mobilized within the environment. Elements essential to human and plant metabolism, such as zinc, when exposed by mining activities, may become hazardous due to elevated concentrations (Aslibekan and Moles, 2003; Wuana and Okiemen, 2011). Humans exposed to potentially toxic metals may experience harmful effects as discussed elsewhere (Nriagu and Pacynar, 1988; Wayne and Ming-Ho, 2005).

The old Edendale lead mine is adjacent to Mamelodi, a township on the eastern outskirts of Pretoria, South Africa. Although all the shafts have been closed, two are still clearly visible. The original mine property is now divided by the R513 highway (Figure 1) and the two main areas of historical activity are approximately $800 \mathrm{~m}$ apart. The mine operated from 1898 to 1938 and exploited a vein containing galena, sphalerite, and pyrite (Jansen, 1977). A total of approximately $5000 \mathrm{t}$ of lead and $1.1 \mathrm{t}$ of silver were produced (Reeks, 2012).

The geological formations in the area belong to the Silverton Group of the Transvaal Supergroup from the Precambrian era (Schröder, Lacassie and Beukes, 2006). This area is characterized by sedimentary rocks (carbonaceous shale and siltstone) as in overlain by Magaliesberg quartzite, currently covered by Cenozoic deposits. The Edendale mine exploited lead mineralization in a vein

\footnotetext{
* Tshwane University of Technology (TUT), South Africa.

+ Faculty of Engineering, Buffalo City Campus, Walter Sisulu University, East London, South Africa.

(C) The Southern African Institute of Mining and Metallurgy, 2019. ISSN 2225-6253. Paper received May 2017; revised paper received Feb. 2018.
} 


\section{Investigation of zinc and lead contamination of soil at the abandoned Edendale mine}

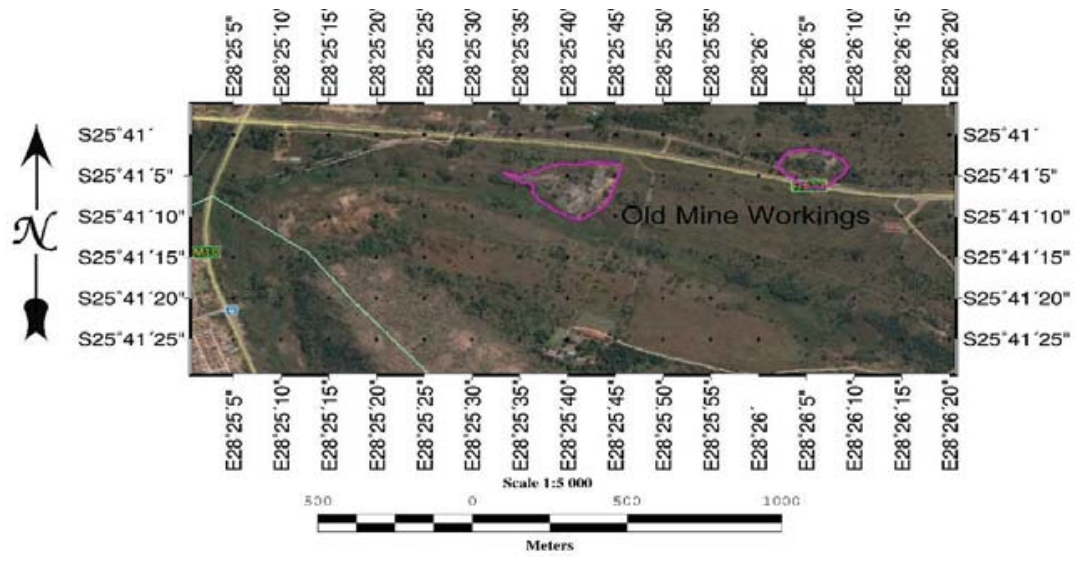

Figure 1-Map of the Edendale mine site, indicating the two mine workings

striking from east to west, with normal faulting (Glass, 2006). This vein is about $2 \mathrm{~m}$ wide and $1170 \mathrm{~m}$ long, dipping $60^{\circ}$ to $85^{\circ}$ southwards. The galena mineralization was erratically distributed within the vein. Galena $(\mathrm{PbS})$, formed through hydrothermal action, constituted most of the lead mineralization. Other, less abundant minerals included sphalerite (ZnFeS) and chalcopyrite $\left(\mathrm{CuFeS}_{2}\right)$.

A tributary of the Edendale Spruit runs from northwest to southeast through the area and drains into the Roodeplaat Dam, a major water reservoir servicing formal and informal settlements, industries, and agriculture in the area (DWAF 2000). Mobilized toxic elements are known to accumulate in river sediments and could contribute to pollution of water resources (Schulin, Geiger, and Furrer, 1995; Patra et al., 2004).

Modern elemental analysis of soil employs various techniques, including atomic absorption spectrometry (AAS), inductively coupled plasma-optical emission spectrometry (ICP-OES), and inductively coupled plasma-mass spectrometry (ICP-MS). These techniques require tedious sample collection and preparation steps, the use of costly and hazardous solvents, as well as drying and digestion of soil samples. Surveys to assess soil pollution are therefore expensive and time-consuming (Higueras et al., 2012). These factors may prevent regular soil studies in developing countries, particularly in Africa. The use of a field-portable $\mathrm{X}$-ray fluorescence (pXRF) spectrometer eliminates all of these disadvantages (Higueras et al. 2012).

A study conducted on surface soils in France, to compare the elemental data obtained using both pXRF and ICP-OES spectrometry, indicated that the pXRF results correlate well with the ICP-OES results (Bonnard and Bour, 2008). An assessment of lead contamination of soils in Ghana and the village Silvermines in Ireland, as well as at Rodalquilar, Spain, were conducted using pXRF (Radu and Diamond 2009; Peinado et al., 2010; Itai et al., 2014). Fujimori and Takigami (2014) also used pXRF to investigate copper, zinc and lead contamination of surface soil at an electronic waste recycling workshop in Manilla in the Philippines.

This investigation was aimed at evaluating the extent of pollution at the abandoned Edendale mine to assess the risk that zinc and lead toxicity poses to local communities. The application of a pXRF spectrometer for establishing the levels of a potentially toxic metal contaminating a large tract of land was appraised. The results were compared to those from ICPOES to evaluate the reliability of the portable instrument. Previous assessments of toxic elements in soils in South Africa were done using ICP-OES, ICP-MS, and AAS (Okonkwo and Maribe 2004; Monna et al., 2006; Chutas et al., 2011; Mtunzi, Dikio, and Moja, 2015). No previous surveys of metal pollution of soils performed locally using pXRF spectrometry could be found in the literature. This study therefore serves as a baseline for toxic metal determination using this rapid and convenient technique. The data obtained was used to construct zinc and lead contamination maps for the area.

\section{Materials and methods}

\section{Field-portable XRF spectrometer}

In-situ analyses of soils were carried out using a pXRF (Thermo Scientific Niton XL3t GOLDD+, Tewksbury, USA) spectrometer. A calibration curve was constructed after repeated analyses $(n=4)$ of the certified reference materials (CRMs) NIST2709a and NIST2780 (National Institute of Standards and Technology, USA), TILL-4 (Natural Resources Canada), and AMIS0157 and AMIS015 (African Mineral Standards, South Africa). A measurement time of 45 seconds, corresponding to the excitation time of the main elements, was used. The internal fundamental parameter calibration (mining mode) was adjusted by uploading the slope and intercept values of the constructed calibration curve. Contamination and drift of the instrument were assessed using the RCRA-certified reference material (Resource Conservation and Recovery Act, USA).

\section{Sample collection and field measurements}

The area was divided into two sites: Site 1 (approximately $250 \mathrm{~m} \times 400 \mathrm{~m})$ north of the R513 and Site $2(400 \mathrm{~m} \times 1$ $200 \mathrm{~m}$ ), to the south of the road. A sampling grid was established with measurement and sampling positions $50 \mathrm{~m}$ apart. Measurements of the points on the grid $(n=167)$ commenced, but were terminated when the values were below background levels of $50 \mathrm{mg} / \mathrm{kg}$ (Figure 2).

At each measurement point, the probe of the analyser was placed in contact with the soil after removing surface debris such as dead leaves, branches, vegetation, and stones. Topsoil samples ( $n=167$ ) were collected from a depth of 0 to 


\section{Investigation of zinc and lead contamination of soil at the abandoned Edendale mine}

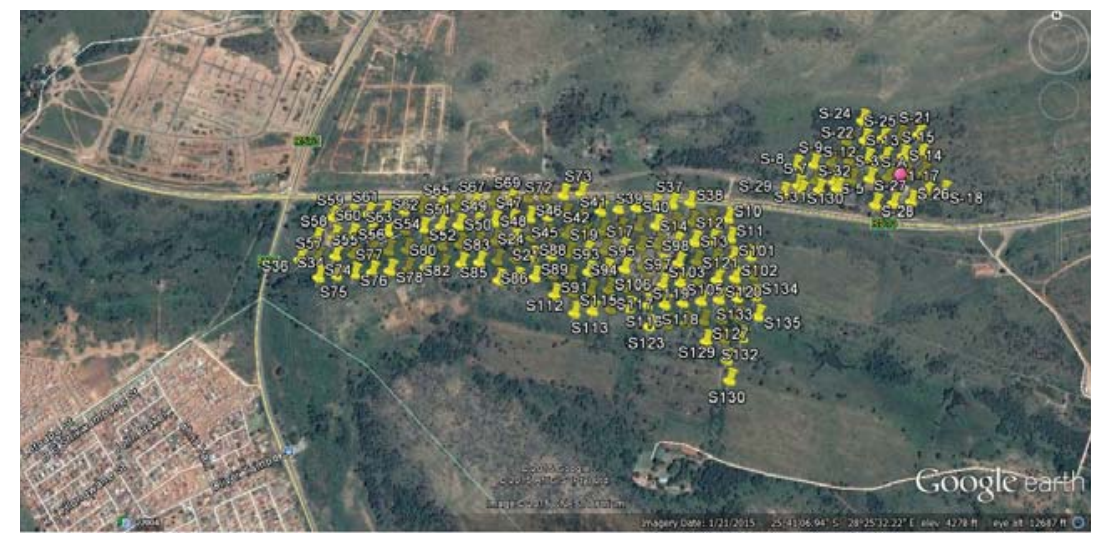

Figure 2-Sampling design of the study site, Mamelodi North, Pretoria, South Africa

$15 \mathrm{~cm}$ using a hand auger. The study was limited to surface samples to reflect the possible exposure of humans to contaminants. Soil samples $(1 \mathrm{~kg})$ were placed in sealable polyethylene bags and stored appropriately for further laboratory analysis.

Global positioning system (GPS) coordinates for each sample, combined with the zinc and lead concentrations determined in the soils, were plotted using the software developed in-house by C.J.S. Fourie. The gridding of the data was performed using the USGS software and the maps were produced using the ER-Mapper 2011 software. After construction, the zinc and lead contamination maps were overlaid onto the Google map of the area.

\section{Soil digestion and ICP-OES analysis}

A subset of soil samples $(n=36)$, representing low, medium, and high levels of zinc and lead contamination as determined by pXRF, was randomly selected. Approximately $0.25 \mathrm{~g}$ portions of air-dried and sieved ( $2 \mathrm{~mm}$ mesh) soil samples were accurately weighed into microwave vessels, followed by the addition of $3.0 \mathrm{~mL}$ of nitric acid (Suprapur) and $2.0 \mathrm{~mL}$ of hydrofluoric acid (AR grade), which were purchased from Merck (Darmstadt, Germany). A microwave oven (Mars 5, CEM Corporation, Matthews, USA) was used for digestion. The heating programme involved ramping to $175^{\circ} \mathrm{C}$ over 20 minutes and holding at temperature for 15 minutes before cooling for 15 minutes. Saturated boric acid $(2.0 \mathrm{~mL})$ (Merck, Modderfontein, South Africa) was added and digestion was continued by applying the same heating programme. The digests were diluted with double-deionized water and analysed using ICP-OES (Spectro Arcos, Spectro, Kleve, Germany).

\section{Method validation}

To validate the analytical methods, the soil CRMs (RCRA, NIST2780, AMIS0153, and AMIS 0157) were analysed using both techniques. Relative standard deviations (RSDs), calculated from seven replicable analyses of the CRMs, permitted the precision of the analytical methods to be evaluated. The accuracy of each method was estimated from the percentage recovery calculated from the certified values for zinc and lead. The limits of detection (LODs) of the pXRF method for zinc and lead were statistically estimated as three times the standard deviation of seven replicate analyses of the reference material RCRA (Bernick et al., 1995). For ICPOES, the LODs were obtained from regression analysis of the calibration data.

\section{Results and discussion}

\section{Zinc and lead levels in soil and construction of the contamination maps}

Field analysis of the soil of the area indicated that zinc concentrations ranged from 18 to $7300 \mathrm{mg} / \mathrm{kg}$, and those of lead from 50 to $21000 \mathrm{mg} / \mathrm{kg}$ (Figure 3). Low levels were attributed to natural background concentrations, whereas high concentrations were associated with soil contamination. The concentrations of the toxic metals in soils at the old Edendale mine are significantly higher than the baseline values of $185 \mathrm{mg} / \mathrm{kg}$ for zinc and $56 \mathrm{mg} / \mathrm{kg}$ for lead reported for South African agricultural soils and set as the maximum threshold value for unpolluted soils (Herselman, Steyn, and Fey, 2005; Herselman, 2007). Of the 167 sampling points analysed, $46 \%$ had zinc readings higher than the baseline value, and $77 \%$ for lead. A lead threshold value of 7600 $\mathrm{mg} / \mathrm{kg}$ in waste destined for landfill was published in the South African Government Gazette (13 August 2013) as an amendment to the Waste Classification and Management Regulations: Waste Act (Act No. 59 of 2008) (DWEA 2013).

Lead levels in soils from the three highly contaminated areas, indicated in red on the map of the old Edendale mine (Figure 4), surpassed this established limit for lead in waste, and $3 \%$ of the samples analysed were two to three times higher than this threshold value. However, none of the samples exceeded the threshold value of $640000 \mathrm{mg} / \mathrm{kg}$ established for zinc by the Act. The contamination maps highlight the zinc and lead pollution profiles of the area. The three areas of lead contamination correspond to the following GPS coordinates: the first (S 25.68403, E 28.43544') surrounds Site 1, with a maximum lead concentration of $8100 \mathrm{mg} / \mathrm{kg}$, while the second (S 25.68470 ${ }^{\circ}$ E 28.42690 $)$ is situated at Site 2, containing up to $20000 \mathrm{mg} / \mathrm{kg}$. A third highly contaminated centre ( $25.68420^{\circ}, \mathrm{E} 28.42190^{\circ}$ ) is evident (Figure 4 ) in the southeastern section of Site 2 (21 $000 \mathrm{mg} / \mathrm{kg}$ ). Maximum zinc levels of 5200 (S2-4) and $7300 \mathrm{mg} / \mathrm{kg}$ (S2-52) were found in samples from the most highly lead-contaminated regions at Site 2 , whereas high zinc concentrations at Site 1 were noted in samples S1-19 


\section{Investigation of zinc and lead contamination of soil at the abandoned Edendale mine}

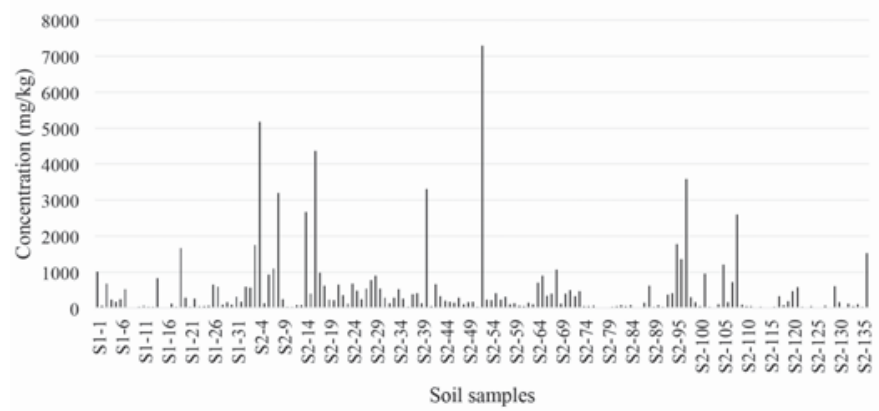

b

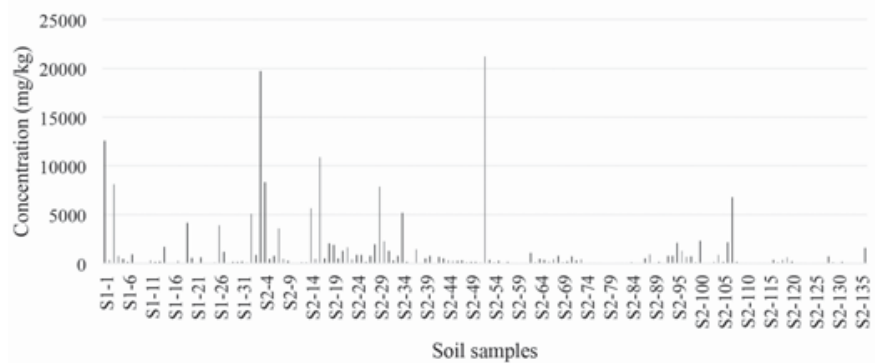

Figure 3-Zinc and lead concentrations $(\mathrm{mg} / \mathrm{kg})$ in soils at the old Edendale mine, measured according to the sampling grid using pXRF

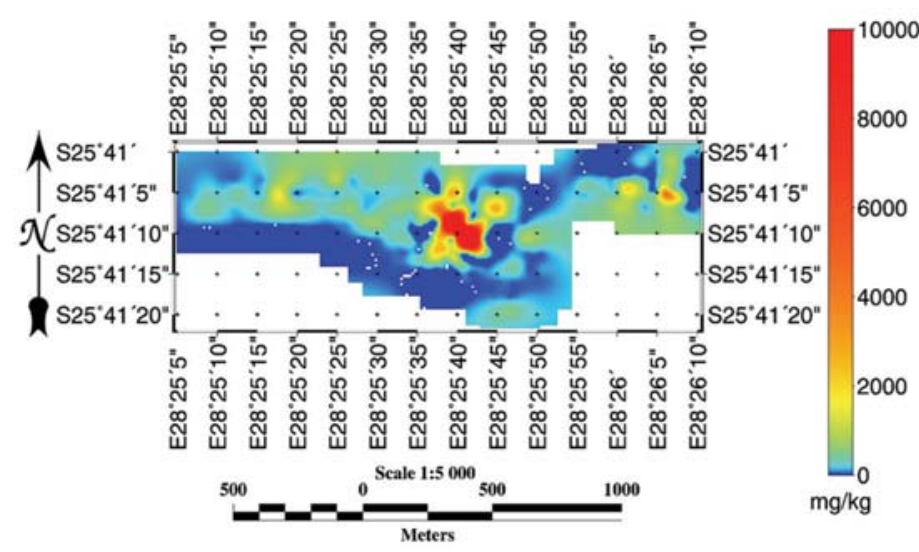

b

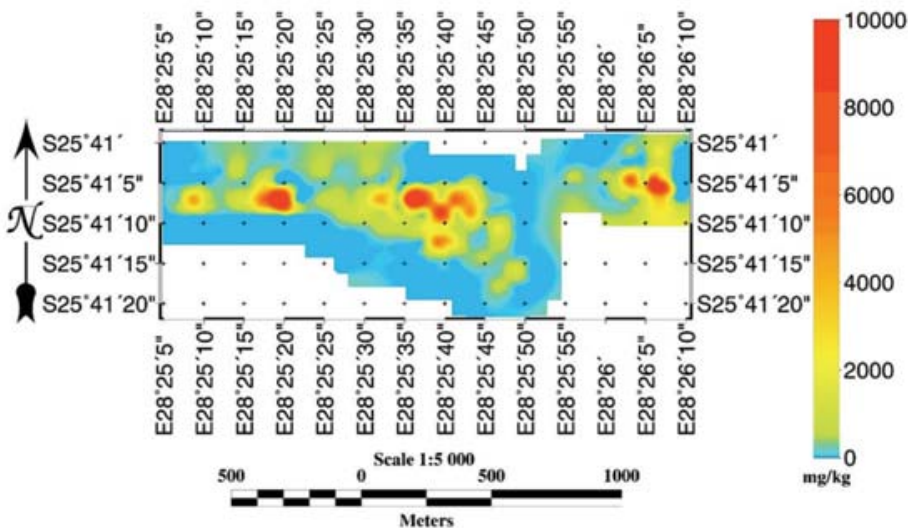

Figure 4-Zinc (a) and lead (b) contamination maps of soil at the old Edendale mine 


\section{Investigation of zinc and lead contamination of soil at the abandoned Edendale mine}

$\left(\mathrm{S} 25.68520^{\circ}, \mathrm{E} 28.42640^{\circ}\right)$. Although the highest zinc concentrations were lower than those of lead, the spatial distribution of high zinc levels coincides with the lead contamination.

Zinc and lead concentrations at the mine are substantially higher than the threshold target and intervention values for soil quality standards $(140 ; 720 \mathrm{mg} / \mathrm{kg})$ and $(85$; $530 \mathrm{mg} / \mathrm{kg}$ ), respectively, set by the EC (Rösner and van Schalkwyk 2000). The EC countries have also established screening values for metals that pose an unacceptable risk to human health. Belgium, probably the most tolerant in this regard, recommends a maximum of 700 and $2500 \mathrm{mg} / \mathrm{kg}$ for lead and 1000 and $3000 \mathrm{mg} / \mathrm{kg}$ for zinc in soils used for residential and industrial purposes, respectively (Carlon, D'Alessandro, and Swartjes, 2007). These levels are exceeded by the concentrations measured at the Edendale mine. Investigations conducted at abandoned lead plants resulted in similar findings. The highest concentrations determined in soil of an abandoned lead ore treatment plant in CongoBrazzaville were $2400 \mathrm{mg} / \mathrm{kg}$ for zinc and $11800 \mathrm{mg} / \mathrm{kg}$ for lead (Matini, Ongoka, and Tathy, 2011), whereas in Poland, the maximum concentrations measured were 6150 and $13600 \mathrm{mg} / \mathrm{kg}$ for zinc and lead, respectively (Karczewska et al., 2006). An even worse scenario was reported from Nigeria, where lead levels ranged from 243 to $126000 \mathrm{mg} / \mathrm{kg}$ in soils in the vicinity of a battery manufacturing plant (Adie and Osibanjo 2009). In the current study, the contamination maps, integrated with the Google map of the area, provide a clear visual summary of zinc and lead pollution at the Edendale lead mine (Figure 5). These identified zones of high contamination are probably due to landfill with rock waste and stockpiles of lead ore from the mine (Matini, Ongoka, and Tathy, 2011; Rösner and van Schalkwyk 2000). These hotspots have their centres at the following GPS coordinates: $\left(\mathrm{S} 25.68403^{\circ}, \mathrm{E} 28.43544^{\circ}\right)$; (S $25.68470^{\circ}, \mathrm{E} 28.42690^{\circ}$ ) and $\left(\mathrm{S} 25.68420^{\circ}, \mathrm{E} 28.42190^{\circ}\right)$.

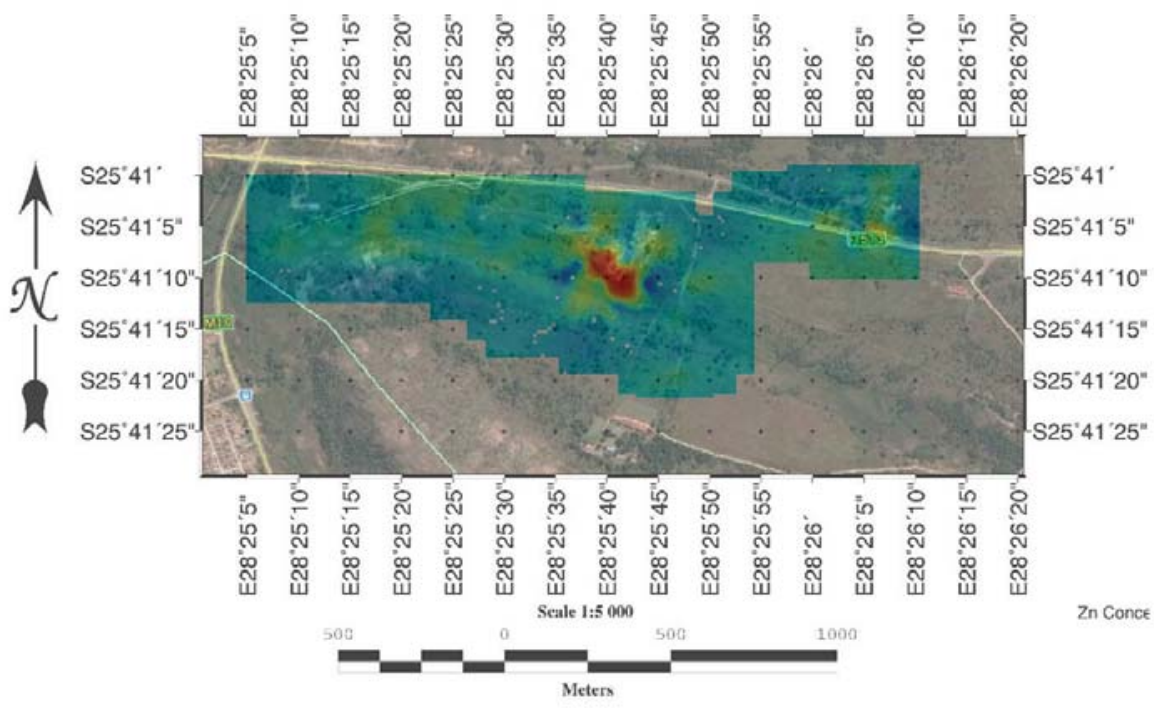

b

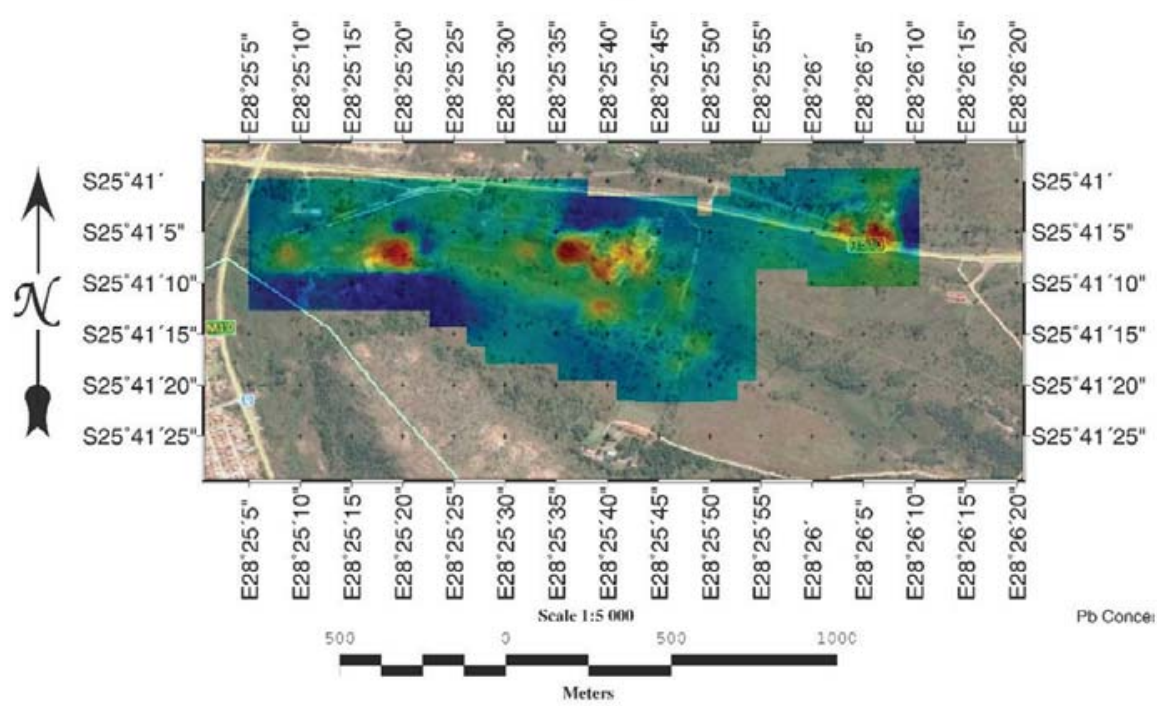

Figure 5-Zinc (a) and lead (b) contamination at the old Edendale Mine, superimposed on aerial photography (Google Earth) 


\section{Investigation of zinc and lead contamination of soil at the abandoned Edendale mine}

Zinc and lead pollution of soils at the Edendale mine may pose a serious risk to animals and humans living in the vicinity of the mine. Currently, the contaminated site is being used for small-scale agriculture; however, there are indications that the area is being considered for urban development. Recent research suggests that lead is absorbed by, and is translocated between, plant parts, resulting in metal migration up the food chain (Marwa, Meharg, and Rice, 2012; Salazar and Pignata, 2014). A study conducted in China confirmed that consumption of rice and vegetables cultivated on lead-contaminated soils resulted in a high daily intake of the toxic metal (Zhuang et al. 2009).

Micronutrients such as zinc may become harmful to plants when present at excessive concentrations in soil (Nagajyoti, Lee, and Sreekanth, 2010). Intawongse and Dean (2006) demonstrated that increased zinc concentrations in compost result in an increase in the uptake of the metal by vegetables. We are concerned that the polluted site at the Edendale mine presents a significant hazard to people living in the area, since we witnessed, during sampling, the collection of contaminated soil and gravel for construction by the local community. A primary school and farms, which rely on the use of borehole water, are located in area.

Furthermore, contamination of the Edendale Spruit will result in the transport of toxic elements to the Roodeplaat Dam. More in-depth investigations are needed to assess the risk posed to the environment and the health of people living in the area.

\section{Confirmatory results from ICP-OES}

The results obtained by pXRF were benchmarked against those obtained by ICP-OES. These results followed similar trends (Figure 6). However, in some cases, the lead values measured by $\mathrm{pXRF}$ were higher.
The small discrepancies between the results may be attributed to various factors, including differences in soil homogeneity, moisture, soil particle size, and the lack of a flat surface for measurement (Argyraki, Ramsey, and Potts, 1997; Parsons et al., 2013). The correlation coefficients (zinc: $\mathrm{r}^{2}=0.99$; lead: $\mathrm{r}^{2}=0.95$ ) obtained from regression analysis were above 0.7 , which is the minimum correlation level set for screening data (Bernick et al., 1995; Kalnicky and Singhvi, 2001; US EPA, 2007). The $\mathrm{r}^{2}$ values indicate excellent correlation between the techniques and prove that pXRF spectrometry is an appropriate technique for screening soil at the old Edendale mine.

\section{Quality control of the analytical methods}

Results for the precision, accuracy, and limits of detection (LOD) of the PXRF and the ICP-OES techniques are summarized in Table I for zinc and Table II for lead. For the pXRF, average relative standard deviations (RSDs) of 1.9\% (zinc) and $0.86 \%$ (lead) were obtained for the CRMs, reflecting good precision for zinc and lead determination. A precision lower than the $20 \%$ recommended by the United States Environmental Protection Agency Method 6200 (US EPA, 2007) for pXRF analysis was achieved. A mean RSD of $5 \%$ was obtained for zinc when using the ICP-OES technique, whereas a RSD of $9 \%$ (ranging from $7 \%$ to $11 \%$ ) was achieved for zinc. Average recoveries of $101 \%$ and $104 \%$ (ranging from 94 to $112 \%$ and from 100 to $110 \%$ ) were established for pXRF for zinc and lead, respectively, while 94\% and 91\% respectively were obtained for the ICP-OES method. Limits of detection of 16.9 and $17.4 \mathrm{mg} / \mathrm{kg}$ for the $\mathrm{pXRF}$ and 0.0028 and $0.216 \mathrm{mg} / \mathrm{kg}$ for the ICP-OES were established for zinc and lead, respectively.
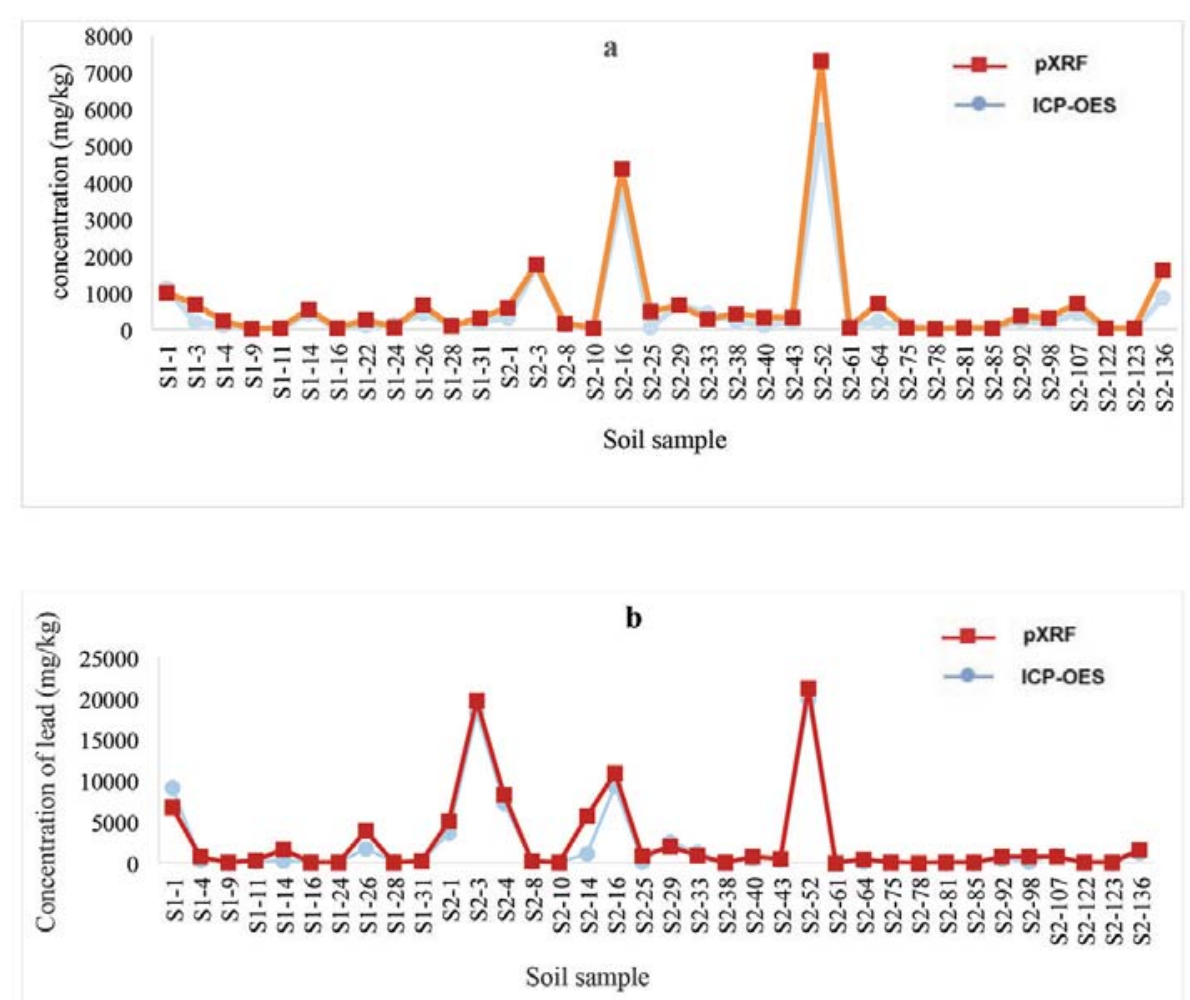

Figure 6- Trends of (a) zinc and (b) lead concentrations in soil at the Edendale mine as determined by pXRF and ICP-OES spectrometry 


\section{Investigation of zinc and lead contamination of soil at the abandoned Edendale mine}

\begin{tabular}{|c|c|c|c|c|}
\hline \multicolumn{5}{|c|}{$\begin{array}{l}\text { Values for RSD, recovery, and LOD obtained from analyses of certified reference } \\
\text { materials and standards for the determination of the precision, accuracy of the } \\
\text { pXRF and ICP-OES methods for zinc }\end{array}$} \\
\hline CRM & $\begin{array}{c}\text { pXRF } \\
\text { NIST 2709a }\end{array}$ & NIST 2780 & AMIS0153 & $\begin{array}{l}\text { ICP-OES } \\
\text { AMIS0153 }\end{array}$ \\
\hline Certified value $(\mathrm{Zn})(\mathrm{mg} / \mathrm{kg})$ & 103 & 2570 & 88400 & 88400 \\
\hline Means (mg/kg) & 116 & 2420 & 86914 & 82851 \\
\hline RSD (\%) & 4.9 & 0.40 & 0.49 & 5 \\
\hline Recovery (\%) & 112 & 94 & 98 & 94 \\
\hline LOD & & 16.9 & & 0.0028 \\
\hline
\end{tabular}

\begin{tabular}{|c|c|c|c|c|c|}
\hline \multicolumn{6}{|c|}{$\begin{array}{l}\text { Table II } \\
\text { Values for RSD, recovery, and LOD obtained from analyses of certified reference } \\
\text { materials and standards for the determination of the precision, accuracy of the } \\
\text { pXRF and ICP-OES methods for lead }\end{array}$} \\
\hline \multirow[b]{2}{*}{ CRM } & \multicolumn{3}{|c|}{ pXRF } & \multicolumn{2}{|r|}{ ICP-OES } \\
\hline & RCRA & NIST 2780 & AMIS 0153 & AMIS 0157 & AMIS 0153 \\
\hline Certified value $(\mathrm{Pb})(\mathrm{mg} / \mathrm{kg})$ & 500 & 5770 & 10191.00 & 3432.00 & 10191.00 \\
\hline Mean (mg/kg) & 551 & 5750 & 10486 & 2827 & 9972 \\
\hline RSD (\%) & 1.0 & 0.67 & 0.86 & 7.0 & 11 \\
\hline Recovery (\%) & 110 & 100 & 103 & 83 & 98 \\
\hline LOD (mg/kg) & 17.4 & 0.216 & & & \\
\hline
\end{tabular}

\section{Conclusions}

This study has revealed unacceptably high concentrations of lead in soil in the vicinity of the abandoned Edendale mine, with measurements as high as $21000 \mathrm{mg} / \mathrm{kg}$. Zinc was also found at elevated concentrations ( $8100 \mathrm{mg} / \mathrm{kg})$. These high levels pose a risk to humans and livestock. Maps were constructed from the data to pinpoint the contamination hotspots and three anomalous centres of extreme lead contamination, one of which coincides with extreme zinc contamination, were identified. These maps will be of value to local authorities responsible for housing developments.

Initially, the values obtained by pXRF appeared to be unrealistically high, but these were confirmed by ICP-OES with good correlation. In addition, the results obtained for the analysis of CRMs demonstrated that pXRF spectrometry can be used with confidence to rapidly assess zinc and lead pollution of large areas of land, such as abandoned mines. Based on the performance of the pXRF in field determination of high concentrations of zinc and lead in soil at the abandoned Edendale mine site, the spectrometer can be recommended as a screening tool for fast assessment of zinc and lead pollution of soils in South Africa. Further investigations may be warranted to determine whether the methodology might be usefully extended to other contaminants. An in-depth soil contamination assessment should be done, since the soil texture and composition may affect the mobility and availability of potentially toxic metals.

\section{References}

AsLibEKAn, O. and MoLEs, R. 2003. Environmental risk assessment of metals contaminated soils at Silvermines abandoned mine site, Co Tipperary, Ireland. Environmental Geochemtry and Health, vol. 25. pp. 247-266.

Adie, G.U. and Osibanjo, O. 2009. Assessment of soil-pollution by slag from an automobile battery manufacturing plant in Nigeria. African Journal of Environmental Science and Technology, vol. 3. pp. 239-250.

Argyraki, A., Ramsey, M.H., and PotTs, P.J. 1997. Evaluation of portable X-ray fluorescence instrumentation for in situ measurements of lead on contaminated land. The Analyst, vol. 122, no. 8. pp. 743-749.

Bernick, M.B., GetTy, D., Prince, G., and Sprenger, M. 1995. Statistical evaluation of field-portable X-ray fluorescence soil preparation methods. Journal of Hazardous Materials, vol. 43, no. 2. pp. 111-116.

BonnaRD, R. and BouR, O. 2008. Comparison of lead concentration in surface soil by induced coupled plasma/optical emission spectrometry and X-ray fluorescence. Proceedings of the 10th International UFZ-Deltares/TNO Conference on Management of Soil, Groundwater \& Sediments (CONSOIL 2008), Milan, Italy. Helmholtz Centre for Environmental Research, Leipzig. pp. 308-313.

Carlon, C., D'Alessandro, M., and Swartjes, F. 2007. Derivation methods of soil screening values in Europe. A review and evaluation of national procedures towards harmonisation. European Commission. Joint Research Centre, Ispra, EUR 22805-EN. pp. 306.

Chutas, N.I., Bates, E., Prevec, S.A., Coleman, D.S., and Boudreau, A.E. 2011. $\mathrm{Sr}$ and $\mathrm{Pb}$ isotopic disequilibrium between coexisting plagioclase and orthopyroxene in the Bushveld Complex, South Africa: microdrilling and progressive leaching evidence for sub-liquidus contamination within a 


\section{Investigation of zinc and lead contamination of soil at the abandoned Edendale mine}

crystal mush. Contributions to Mineralogy and Petrology, vol. 163. no. 4. pp. 653-668.

DWAF. 2000. Pollution incident in the Roodeplant Dam. Department of Water Affairs and Forestry, Pretoria.

http://www.dwaf.gov.za/iwqs/leports/carin/lpd2000\%5F2/exec [accessed 22 September 2015].

DWEA. 2013. Amendment to the Waste Classification and Management Regulation: Waste Act (Act 59 of 2008). Department of Water Affairs and Environment, Pretoria

https://www.environment.gov.za/sites/default/files/legislations/ [accessed: 7 June 2016].

Fujimori, T. and TAKigami, H. 2014. Pollution distribution of heavy metals in surface soil at an informal electronic-waste recycling site. Environmental Geochemistry and Health, vol. 36, no. 1. pp. 159-168.

GLASS, J. 2006. The environmental impact of the abandoned lead mine near Tshwane, South Africa. MSc dissertation, University of Johannesbourg.

HERSELMAN, J.E. 2007. The concentration of selected trace metals in South African soil. PhD thesis, University of Stellenbosch. http://hdl.handle.net/10019.1/1390

Herselman, J.E., Steyn, C.E., and Fey, M.V. 2005. Baseline concentration of Cd, $\mathrm{Co}, \mathrm{Cr}, \mathrm{Cu}, \mathrm{Pb}, \mathrm{Ni}$ and $\mathrm{Zn}$ in surface soils of South Africa. South African Journal of Science, vol. 101. pp. 509-512.

Higueras, P., Oyarzun, R., Iraizoz, J.M., Lorenzo, S., Esbrí, J.M., and MartínezCoronado, A. 2012. Low-cost geochemical surveys for environmental studies in developing countries: Testing a field portable XRF instrument under quasi-realistic conditions. Journal of Geochemical Exploration, vol. 113. pp. 3-12

INTAWONGSE, M. and DEAN, J.R. 2006. Uptake of heavy metals by vegetable plants grown on contaminated soil and their bioavailability in the human gastrointestinal tract. Food Additives and Contaminants, vol. 23, no. 1. pp. 36-48.

ItaI, T., OTsuKa, M., AsAnte, K.A., Muto, M., OpoKu-AnKomah, Y., AnsA-Asare, O.D., and TANABE, S. 2014. Variation and distribution of metals and metalloids in soil/ash mixtures from Agbogbloshie e-waste recycling site in Accra, Ghana. Science of the Total Environment, vol. 471. pp. 707-716.

JANSEN, H. 1977. The geology of the country around Pretoria. British Geological Survey. http://www.bgs.ac.uk/sadc/fulldetails.cfm?id=ZA1463 [accessed 18 September 2015].

KaLA, P. 2010. Trace element contents in European species of wild growing edible mushrooms: A review for the period 2000-2009. Food Chemistry, vol. 122 , no. 1. pp. 2-15.

KALNICKY, D.J. and SinghVI, R. 2001. Field portable XRF analysis of environmental samples. Journal of Hazardous Materials, vol. 83, no. 2. pp. 93-122.

Karczewska, A., Bogda, A., Galka, B., Szulc, A., Czwarkiel, D., and Duszynska, D. 2006. Natural and anthropogenic soil enrichment in heavy metals in areas of former metallic ore mining in the Sudety MTS. Polish Journal of Soil Science, vol. 15, no. 2a. pp. 7-9.

Marwa, E.M.M., MEharg, A.A., and Rice, C.M. 2012. Risk assessment of potentially toxic elements in agricultural soils and maize tissues from selected districts in Tanzania. Science of the Total Environment, vol. 416. pp. 180-186.

Matini, L., OngoKA, P., and TATHY, J. 2011. Heavy metals in soil on spoil heap of an abandoned lead ore treatment plan SE Congo-Brazzaville. African Journal of Environmental Science and Technology, vol. 5, no. 2. pp. 89-97.

Monna, F., Poujol, M., Losno, R., Dominik, J., Annegarn, H., and Coetzee, H. 2006. Origin of atmospheric lead in Johannesburg, South Africa. Atmospheric Environment, vol. 40, no. 34. pp. 6554-6566.

Mtunzi, F.M., Diкı, E.D., and MojA, S.J. 2015. Evaluation of heavy metal pollution on soil in Vaderbijlpark, South Africa. International Journal of Environmental Monitoring and Analysis, vol. 3, no. 2. pp. 44-49.
Nagajyoti, P.C., LeE, K.D., and SREeKAnth, V.M. 2010. Heavy metals, occurrence and toxicity for plants: a review. Environmental Chemistry Letters, vol. 8, no. 3. pp. 199-216.

NRIAGu, J.O. and PACYNAR, M.J. 1988. A silent epidemic of environmental metal poisoning. Environmental Pollution, vol. 50. pp. 139-161.

Окоnкwo, J.O. and Maribe, F. 2004. Assessment of lead exposure in Thohoyandou, South Africa. The Environmentalist, vol. 24. pp. 171-178.

Parsons, C., Margul Grabulosa, E., Pili, E., Floor, G.H., Roman-Ross, G., and CHARLET, L. 2013. Quantification of trace arsenic in soils by field-portable X-ray fluorescence spectrometry: Considerations for sample preparation and measurement conditions. Journal of Hazardous Materials, vol. 262. pp. 1213-1222.

Patra, M., Bhowmik, N., Bandopadhyay, B., and Sharma, A. 2004. Comparison of mercury, lead and arsenic with respect to genotoxic effects on plant systems and the development of genetic tolerance. Environmental Experimental Botany, vol. 52. pp. 199-223.

Peinado, F.M., Ruano, S.M., GonzÁlez, M.G.B., and Molina, C.E. 2010. A rapid field procedure for screening trace elements in polluted soil using portable X-ray fluorescence (FP-XRF). Geoderma, vol. 1591, no. 2. pp. 76-82.

RADU, T. and DiAmond, D. 2009. Comparison of soil pollution concentrations determined using AAS and portable XRF techniques. Journal of Hazardous Materials, vol. 171, no. 3. pp. 1168-1171.

ReEKs, G.W. 2012. A history of silver mining in the greater Pretoria region, 1885-1999. Master's dissertation, University of South Africa.

RöSNER, T. and VAN SCHALKWYK, A. 2000. The environmental impoact of gold mine tailings footprints in the Johannesburg region, South Africa. Bulletin of Engineering Geology and the Environment, vol. 59. pp. 137-148.

SAI. 2009. Report of the Auditor General to Parliament on a performance audit of the rehabilitation of abandoned mines. Department of Minerals and Energy, Pretoria. http://cer.org.za/wpcontent/uploads/2011/10/AG_Report_on_abandoned_mines-Oct-2009.pdf [accessed 2 June 2014].

SAlazAr, M.J. and PignatA, M.L. 2014. Lead accumulation in plants grown in polluted soils. Screening of native species for phytoremediation. Journal of Geochemical Exploration, vol. 137. pp. 29-36.

SchröDER, S., LACASSIE, J., and BEUKES, N. 2006. Stratigraphic and geochemical framework of the Agouron drill cores,Transvaal Superrgroup (Neoarchean-Paleoproterozoic, South Africa). South African Journal of Geology, vol. 109. pp. 23-54.

Schulin, R., Geiger, G., and Furrer, G. 1995. Heavy metal retention by soil organic matter under changing environmental conditions. Biogeodynamics of Pollutants in Soils and Sediments: Risk Assessment of Delayed and Non-Linear Responses. Salomons, W. and Stigliani, W.M. (eds.), Springer, Berlin/Heidelberg. pp. 53-85

US EPA. 2007. Field portable X-ray fluorescence spectrometry for the determination of elemental concentrations in soil and sediment. Washington DC.

VAN ScHIE, K. 2012. Taxpayers lumped with R30bn bill to clean up derelict and ownerless mines. The Saturday Star. 16 August 2012.

WAYNE, G.L. and MinG-Ho, Y. 2005. Introduction to environmental toxicology: Impacts of chemicals upon ecological systems. Heavy Metals. Raton, C.P.B. (ed.). Lewis Publishers, London.

WUANA, R.A. and OKIEIMEN, F.E. 2011. Heavy metals in contaminated soils: A review of sources, chemistry, risks and best available strategies for remediation. ISRN Ecology. doi:10.5402/2011/402647.

ZhuAng, P., McBride, M.B., XIA, H., Li, N., and Li, Z. 2009. Health risk from heavy metals via consumption of food crops in the vicinity of Dabaoshan mine, South China. Science of the Total Environment, vol. 407, no. 5. pp. 1551-1561. 